ARTICLE

\title{
Crustal rejuvenation stabilised Earth's first cratons
}

\author{
Jacob A. Mulder (10 ${ }^{1 凶}$, Oliver Nebel ${ }^{1}$, Nicholas J. Gardiner ${ }^{1,2}$, Peter A. Cawood (1) ${ }^{1}$, Ashlea N. Wainwright (10 ${ }^{3} \&$ \\ Timothy J. Ivanic ${ }^{4}$
}

The formation of stable, evolved (silica-rich) crust was essential in constructing Earth's first cratons, the ancient nuclei of continents. Eoarchaean (4000-3600 million years ago, Ma) evolved crust occurs on most continents, yet evidence for older, Hadean evolved crust is mostly limited to rare Hadean zircons recycled into younger rocks. Resolving why the preserved volume of evolved crust increased in the Eoarchaean is key to understanding how the first cratons stabilised. Here we report new zircon uranium-lead and hafnium isotope data from the Yilgarn Craton, Australia, which provides an extensive record of Hadean-Eoarchaean evolved magmatism. These data reveal that the first stable, evolved rocks in the Yilgarn Craton formed during an influx of juvenile (recently extracted from the mantle) magmatic source material into the craton. The concurrent shift to juvenile sources and onset of crustal preservation links craton stabilisation to the accumulation of enduring rafts of buoyant, meltdepleted mantle.

\footnotetext{
${ }^{1}$ School of Earth, Atmosphere and Environment, Monash University, Clayton, VIC, Australia. ${ }^{2}$ School of Earth and Environmental Sciences, University of St. Andrews, St. Andrews, United Kingdom. ${ }^{3}$ School of Geography, Earth and Atmospheric Sciences, University of Melbourne, Parkville, VIC, Australia.

${ }^{4}$ Geological Survey of Western Australia, Department of Mines, Industry Regulation and Safety, East Perth, WA, Australia. ${ }^{凶}$ email: jack.mulder@monash.edu
} 
T he transition between the Hadean and Eoarchaean (approximately $4000 \mathrm{Ma}$ ) marks the time when evolved crustal rocks-the essential building material of continentsstarted to become widely preserved on Earth. The delayed arrival of this stable crust, over $500 \mathrm{Ma}$ after planetary accretion, has traditionally been attributed to the wholesale destruction of pre-existing Hadean crust either by intense meteorite bombardment ${ }^{1}$, mantle overturns $^{2}$, or subduction ${ }^{3}$. However, these models continue to be challenged by discoveries of intact remnants of Hadean crust ${ }^{4,5}$, recycled Hadean zircons in younger rocks ${ }^{6-8}$, and Hadean radiogenic $\mathrm{Pb}$ and ${ }^{142} \mathrm{Nd}$ isotopic signatures in several cratons worldwide ${ }^{5,9-11}$, which indicate that potentially large tracts of Hadean crust survived the Hadean-Eoarchaean transition. An alternative view suggests that the Hadean Earth was surfaced by a predominantly mafic-ultramafic crust, and the Eoarchaean witnessed a fundamental change in crust-forming processes that produced the first widespread stable, evolved crust ${ }^{10,12-14}$. Testing this hypothesis has, however, proved challenging due to the scarcity and geological complexity of the ancient terranes that preserve a record of crust formation spanning the Hadean and Eoarchaean.

Preserved evolved Eoarchaean crust is dominated by rocks of the tonalite-trondjhemite-granodiorite (TTG) suite. TTGs mostly form by a two-stage process: initial extraction of primary mafic crust through partial-melting of the mantle, followed by later partial melting of that mafic crust to form evolved magma ${ }^{15}$. The mafic precursors of TTGs may be either: (i) juvenile reservoirs, which are remelted shortly after being extracted from the mantle and emplaced in the crust; or (ii) ancient reservoirs that have endured in the crust for hundreds of million years. The ${ }^{176} \mathrm{Lu}-{ }^{176} \mathrm{Hf}$ decay system is well-suited to characterising the source of TTGs, as the fractionation of Lu from Hf during partial melting results in the mantle (high ${ }^{176} \mathrm{Lu} /{ }^{177} \mathrm{Hf}$ ) and crust (low ${ }^{176} \mathrm{Lu} /{ }^{177} \mathrm{Hf}$ ) developing distinct time-integrated radiogenic $\mathrm{Hf}$ isotopic compositions. Consequently, Eoarchaean TTGs sourced from juvenile reservoirs inherited the near-chondritic $\mathrm{Hf}$ isotopic composition of the Eoarchaean mantle ${ }^{16,17}$, whereas Eoarchaean TTGs sourced from ancient reservoirs acquired less radiogenic (sub-chondritic) Hf isotopic signatures. Zircon is an ideal tool to study the Hf isotopic character of ancient TTGs as it is a ubiquitous phase in evolved magmas and preserves the Hf isotope signature of its parental melt owing to its low $\mathrm{Lu} / \mathrm{Hf}(<0.001)$ and resilience to isotopic resetting. Coupling in situ $\mathrm{U}-\mathrm{Pb}$ dating and $\mathrm{Hf}$ isotope analysis of zircon provides a time-integrated record of the source characteristics of TTGs, thus offering key insights into evolved crust-forming processes on the early Earth.

Here, we focus on the Yilgarn Craton, Western Australia (Fig. 1), which contains exposures of some of the oldest known evolved Eoarchaean crust $^{18}$ and preserves Earth's most complete temporal archive of Hadean evolved magmatism through $4370-4000 \mathrm{Ma}$ detrital zircons $\mathrm{s}^{6-8,14}$. The Yilgarn Craton therefore provides an important opportunity to examine the nature of evolved magmatism across the critical Hadean-Eoarchaean interval over which the majority of Earth's first stable, evolved crust formed. New zircon $\mathrm{U}-\mathrm{Pb}$ and $\mathrm{Hf}$ isotopic data reveal a link between the onset of crustal preservation in the Yilgran Craton and a fundamental shift in the source characteristics of evolved magmatism across the Hadean-Eoarchaean transition.

\section{Results}

Hadean-Archaean zircon $\mathrm{Hf}$ isotope record of the Yilgarn Craton. The earliest crustal record of the Yilgarn Craton is recorded by Hadean and early Eoarchaean $(>3800 \mathrm{Ma})$ detrital zircons, the majority of which are found in approximately 3000 Ma sedimentary successions in four locations (Fig. 1). The most intensely studied locations include exposures of metamorphosed

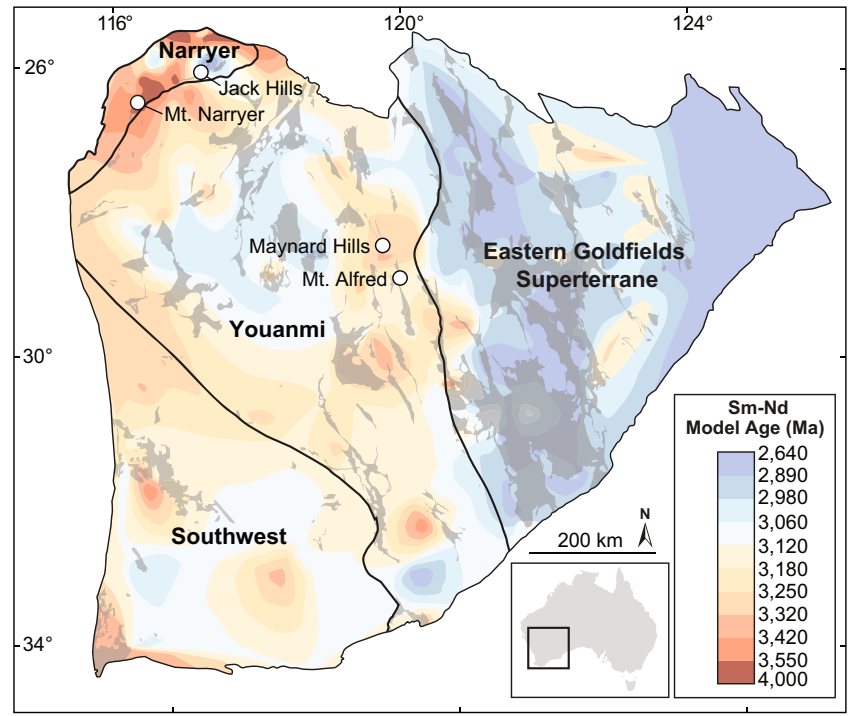

Fig. 1 Tectonic terrane map of the Yilgarn Craton, Western Australia. Main tectonic terranes are labelled and separated by thick black lines. Greenstone belts are shown in dark grey. Contoured Sm-Nd model ages from whole rock analyses are from ref. ${ }^{21}$. and highlight the distribution of ancient crust exposed in the Narryer Terrane and its possible continuation beneath younger sequences in the western part of the craton. White circles mark the location of 3000 Ma sedimentary sequences containing Hadean and early Eoarchaean detrital zircons.

sandstone and conglomerate in the Jack Hills and at Mount Narryer, both within the Narryer Terrane $e^{3,6-8,19}$ (Fig. 1). The other two locations occur approximately $400 \mathrm{~km}$ to the southeast, in the Youanmi Terrane, and include exposures of metamorphosed sandstones of the Illaara Formation in the Maynard Hills and at Mount Alfred ${ }^{20,21}$ (Fig. 1). We complement previously published data from the Jack Hills and Mount Narryer, ${ }^{3,14}$ with a large new $\mathrm{U}-\mathrm{Pb}-\mathrm{Hf}$ isotopic dataset from detrital zircons $(n=$ 2296) from the Illaara Formation. A subset of 638 detrital zircons showing the least evidence for disturbance of their $\mathrm{U}-\mathrm{Pb}$ and $\mathrm{Hf}$ isotope systematics are interpreted to best represent the age and $\mathrm{Hf}$ isotopic composition of their evolved magmatic source rocks (Supplementary Data 1). Our new zircon ages range from 4150 to $3250 \mathrm{Ma}$ and form broad age populations with peaks at approximately $3750,3650,3500$, and $3400 \mathrm{Ma}$ (Fig. 2; Supplementary Fig. 1). These age populations are similar to those observed in detrital zircons of the Jack Hills and Mount Narryer metasedimentary rocks and overlap temporally with early Archaean crust exposed in the Narryer Terrane (Fig. 2; Supplementary Fig. 1). Therefore, the $\sim 3000 \mathrm{Ma}$ sedimentary successions in the Yilgarn Craton are interpreted to provide a broad sampling of the Narryer Terrane and related early Archaean crust that may underlie much of the western Yilgarn Craton ${ }^{21}$ (Fig. 1).

Detrital zircons from the Illaara Formation with ages older than $3800 \mathrm{Ma}$ are uncommon ( $1.5 \%$ of analyses) and yield subchondritic $\mathrm{Hf}$ isotopic compositions. These unradiogenic $\mathrm{Hf}$ isotopic compositions equate to negative $\varepsilon \mathrm{Hf}_{(\mathrm{t})}$ values (the deviation in ${ }^{176} \mathrm{Hf} /{ }^{177} \mathrm{Hf}$ from the chondritic uniform reservoir in parts per 10,000 at the time of zircon crystallisation) and support previous studies of the least disturbed Jack Hills detrital zircons ${ }^{14}$ that suggest most of the earliest evolved magmas in the Yilgarn Craton were not derived from juvenile precursors. Instead, the least disturbed Hadean Jack Hills zircons and the majority of pre- $3800 \mathrm{Ma}$ zircons from the Illaara Formation collectively define an approximately linear $\varepsilon \mathrm{Hf}_{(\mathrm{t})}$-time array initiating at $\varepsilon \mathrm{Hf}_{(\mathrm{t})}=-1.5$ at $4400 \mathrm{Ma}$ and evolving to $\varepsilon \mathrm{Hf}_{(\mathrm{t})}=-3$ 


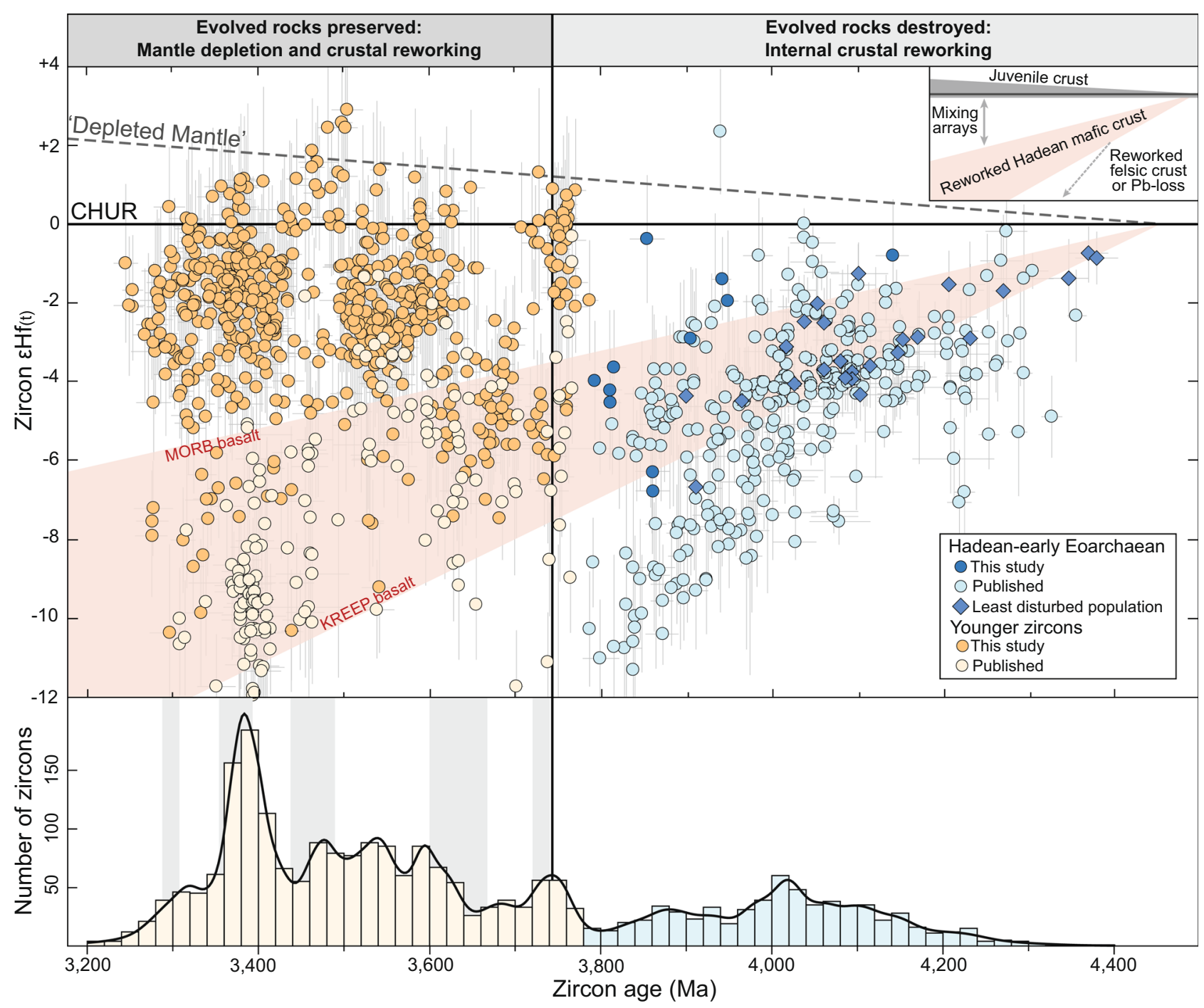

Fig. 2 Plot of initial epsilon hafnium $\left(\varepsilon \mathrm{Hf}_{(t)}\right)$ versus zircon age for Hadean and Archaean detrital zircons from the Yilgarn Craton. Most pre-3800 Ma detrital zircons define a $\mathrm{Hf}$ isotopic array consistent with internal reworking of early Hadean mafic sources such as typical mid ocean ridge basalt (176 $\mathrm{Hf} /$ $\left.{ }^{177} \mathrm{Hf}=0.026\right)$ or Hadean incompatible element enriched lunar basalt (KREEP, ${ }^{176} \mathrm{Lu} /{ }^{177} \mathrm{Hf}=0.020$; ref. ${ }^{14}$.). From $\sim 3750 \mathrm{Ma}$ onwards, detrital zircon age populations define vertical $\varepsilon \mathrm{Hf}_{(\mathrm{t})}$-time groups that reflect mixing between juvenile sources and pre-existing Hadean crust. The grey dashed line defining the depleted mantle is approximately fitted through the most juvenile zircon analyses. Error bars are 2SE. CHUR chondritic uniform reservoir. Only published data collected by concurrent $\mathrm{Pb}-\mathrm{Hf}$ analysis are shown ${ }^{3,14}$. A kernel density estimate curve and histogram of zircon ages (new and previously published) are shown at the bottom of the diagram. The grey bars behind the histogram correspond to the age of crust preserved in the Narryer Terrane ${ }^{18}$.

to -7 by $3800 \mathrm{Ma}$ (Fig. 2). This Hf isotopic array is consistent with formation of the parental magmas of the pre- $3800 \mathrm{Ma}$ zircons through prolonged $(\sim 600 \mathrm{Ma})$ internal reworking of an older, predominantly mafic crust $\left({ }^{176} \mathrm{Lu} /{ }^{177} \mathrm{Hf}=0.020-0.026\right)$ that was extracted from the mantle in the early Hadean ${ }^{14,19}$.

In contrast to the Hadean-early Eoarchaean record, our new zircon data document a step-change in the Hf isotopic evolution of the Yilgarn Craton at $3750 \mathrm{Ma}$ (Fig. 2). From this time onwards, the zircon populations define vertical groups in $\varepsilon \mathrm{Hf}_{(\mathrm{t})}$-time space that are anchored between an approximately chondritic endmember $\left(\varepsilon \mathrm{Hf}_{(\mathrm{t})}=0\right.$ to +1$)$ and the extrapolation of the Hadean mafic crustal reworking trend defined by the pre$3800 \mathrm{Ma}$ zircons. We interpret each of these vertical $\varepsilon \mathrm{Hf}_{(\mathrm{t})}$-time groups to result from the initial extraction of juvenile mafic magma from the mantle, its emplacement into the Hadean mafic crustal substrate sampled by the pre- $3800 \mathrm{Ma}$ zircons, followed by rapid reworking of both the juvenile and Hadean mafic crustal reservoirs to produce evolved magmas (Fig. 2). This multi-source and multi-stage evolution contrasts with the comparatively simple reworking trend defined by the older (>3800 Ma) zircons and signals a fundamental change in the source characteristics of zircon-bearing magmas in the Yilgarn Craton ${ }^{3,13,14}$.

\section{Discussion}

The critical observation revealed by our new zircon-Hf isotope data is that the onset of crustal preservation in the Yilgarn Craton at $\sim 3750 \mathrm{Ma}^{18}$ coincides with the step-change in magmatic source characteristics recorded by detrital zircons (Fig. 2). This finding may implicate a link between crustal rejuvenation-defined here as an influx of isotopically juvenile magma into an ancient crustal substrate - and the stabilisation of evolved Eoarchaean crust. Indeed, a temporal link between a step-change in the Hf isotope evolution and the appearance of the oldest preserved evolved crustal rocks is also evident in several other cratons with welldocumented Hadean-early Eoarchaean zircon archives (Fig. 3a, b). Detrital and xenocrystic Hadean-Eoarchaean zircons in the 
a

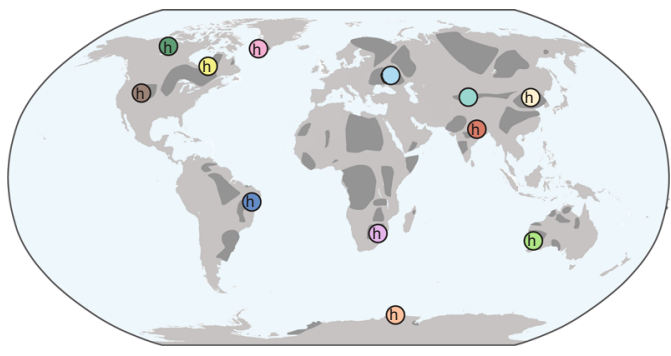

b
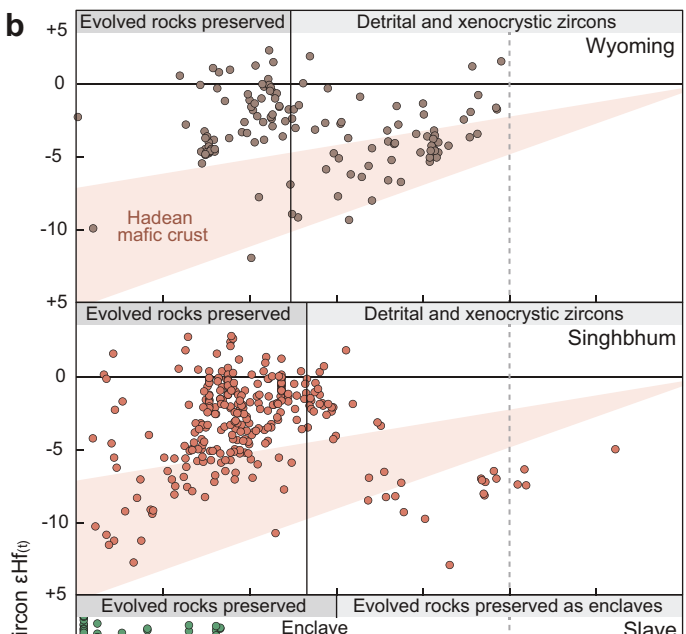

$\stackrel{\sim}{N}$

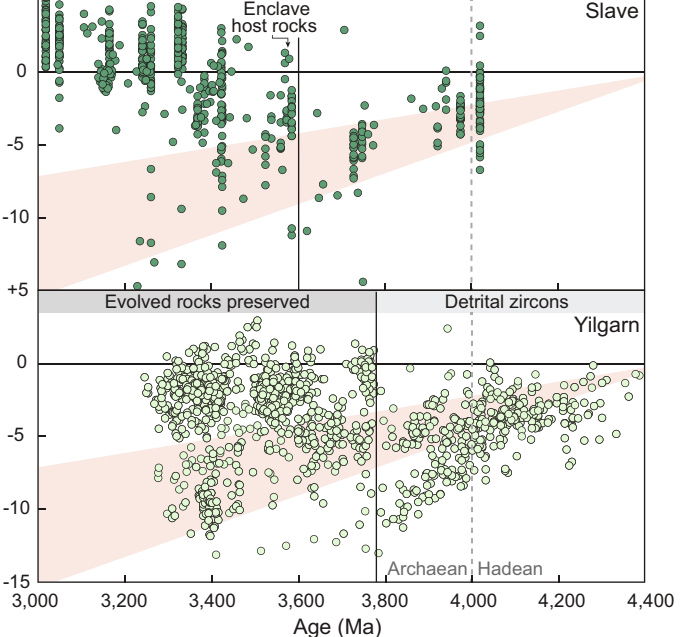

C

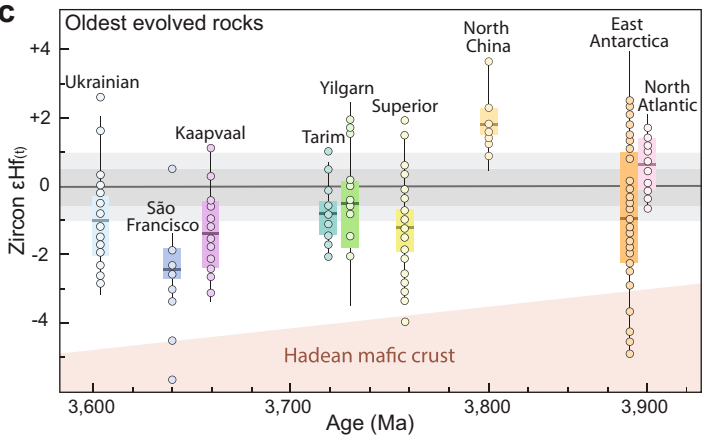

Wyoming and Singhbhum cratons record a prolonged period of reworking of Hadean crust prior to $\sim 3600 \mathrm{Ma}$, followed by a shift to more juvenile sources approximately coincident with the appearance of stable TTGs (Fig. 3b). Internal reworking of Hadean crust was also important in producing the earliest evolved crust in the Slave Craton, which is preserved as decimetre-scale enclaves in the Acasta Gneiss Complex, Canada ${ }^{4}$.
Fig. 3 Zircon Hf isotopic systematics of Earth's oldest evolved rocks. a World map showing Archaean cratons in dark grey (modified from ref. ${ }^{23}$ ). Coloured circles show Eoarchaean cratons with data plotted in panels $\mathbf{b}$ and $\mathbf{c}$. Eoarchaean cratons preserving Hadean zircons, radiogenic $\mathrm{Pb}$, or ${ }^{142} \mathrm{Nd}$ isotopic signatures are labelled ' $h$ '. b Zircon $\varepsilon \mathrm{Hf}_{(\mathrm{t})}$-time plots for Archaean cratons that record a link between a step-shift in $\mathrm{Hf}$ isotope evolution and the preservation of evolved rocks. Black vertical line marks the age of the oldest rock dated by U-Pb zircon geochronology. Dashed grey vertical line shows the Hadean-Eoarchaean boundary. The Hf isotopic evolution of the Hadean mafic crustal reservoir documented in the Yilgarn Craton is shown in red. c Box plots of zircon $\varepsilon \mathrm{Hf}_{(\mathrm{t})}$ data from the oldest TTGs in different Eoarchaean cratons. Box limits define upper and lower quartiles, the thick horizontal line shows the mean, whiskers show $1.5 \mathrm{x}$ interquartile range, points show individual analyses. Horizontal grey bars show chondritic reference values \pm 0.5 and $\pm 1 \varepsilon \mathrm{Hf}$ units. See Supplementary Note 1 for sources and details of compiled data.

The emplacement of the voluminous $\sim 3600$ Ma granitoids hosting these enclaves was synchronous with a pronounced and sustained shift in the Hf isotopic evolution of the Slave Craton to more juvenile sources ${ }^{22}$ (Fig. 3b), indicating a possible causative relationship between crustal rejuvenation and an increase in the volume of stable evolved crust.

Although lacking extensive Hadean zircon archives, the preservation of Hadean $\mathrm{Pb}$ and ${ }^{142} \mathrm{Nd}$ isotopic signatures in many other Eoarchaean cratons ${ }^{23}$ suggests they were built on substrates of Hadean crust ${ }^{9-11}$ (Fig. 3a). Strikingly, the oldest evolved rocks preserved in most Eoarchaean cratons have near-chondritic mean zircon $\mathrm{Hf}$ isotopic compositions that require an important contribution from juvenile precursors in their formation (Fig. 3c, ref. ${ }^{17}$ ). However, the spread from suprachondritic (positive $\varepsilon \mathrm{Hf}_{(\mathrm{t})}$ ) to less radiogenic (negative $\varepsilon \mathrm{Hf}_{(\mathrm{t})}$ ) endmembers implies that these TTGs were not purely juvenile additions to the crust, but were emplaced within, and extensively reworked their Hadean crustal substrates ${ }^{24}$. In summary, the $\mathrm{Hf}$ isotope data from other ancient terranes are consistent with the more temporally complete archive of Hadean-Eoarchaean evolved magmatism preserved in the Yilgarn Craton and support a temporal link between crustal rejuvenation and the stabilisation of the Earth's oldest cratons in the Eoarchaean.

The temporal link between crustal rejuvenation and stabilisation is readily explained by the formation of lithospheric mantle beneath nascent Eoarchaean cratons. The removal of iron and volatile components during partial melting of the mantle to form juvenile magma produces a buoyant and rigid residue of meltdepleted lithospheric mantle ${ }^{25,26}$. The enhanced mechanical strength and buoyancy of this melt-depleted residue stabilises it against erosion by the convecting mantle. Roots of strongly depleted lithospheric mantle, locally $>200 \mathrm{~km}$ thick, are found beneath most Archaean cratons and are widely interpreted to have facilitated the long-term preservation of the overlying crust $^{25-28}$. This empirical evidence for a link between crustal stabilisation and the development of lithospheric mantle is supported by numerical models that demonstrate that even with a more vigorously convecting mantle on a hotter early Earth, the presence of lithospheric mantle substantially increases the preservation potential of crust $^{29,30}$. Dating of the lithospheric mantle beneath Archaean cratons indicates that it mostly formed synchronously with the overlying crust, reinforcing the coupled development of stable crust and lithospheric mantle 27,28 . Importantly, lithospheric mantle xenoliths from several cratons with Re-Os mantle model ages in excess of $3600 \mathrm{Ma}^{27}$ and rare exposures of $\sim 3800$ Ma melt-depleted mantle rocks ${ }^{31}$ provide independent evidence for the development of lithospheric mantle 

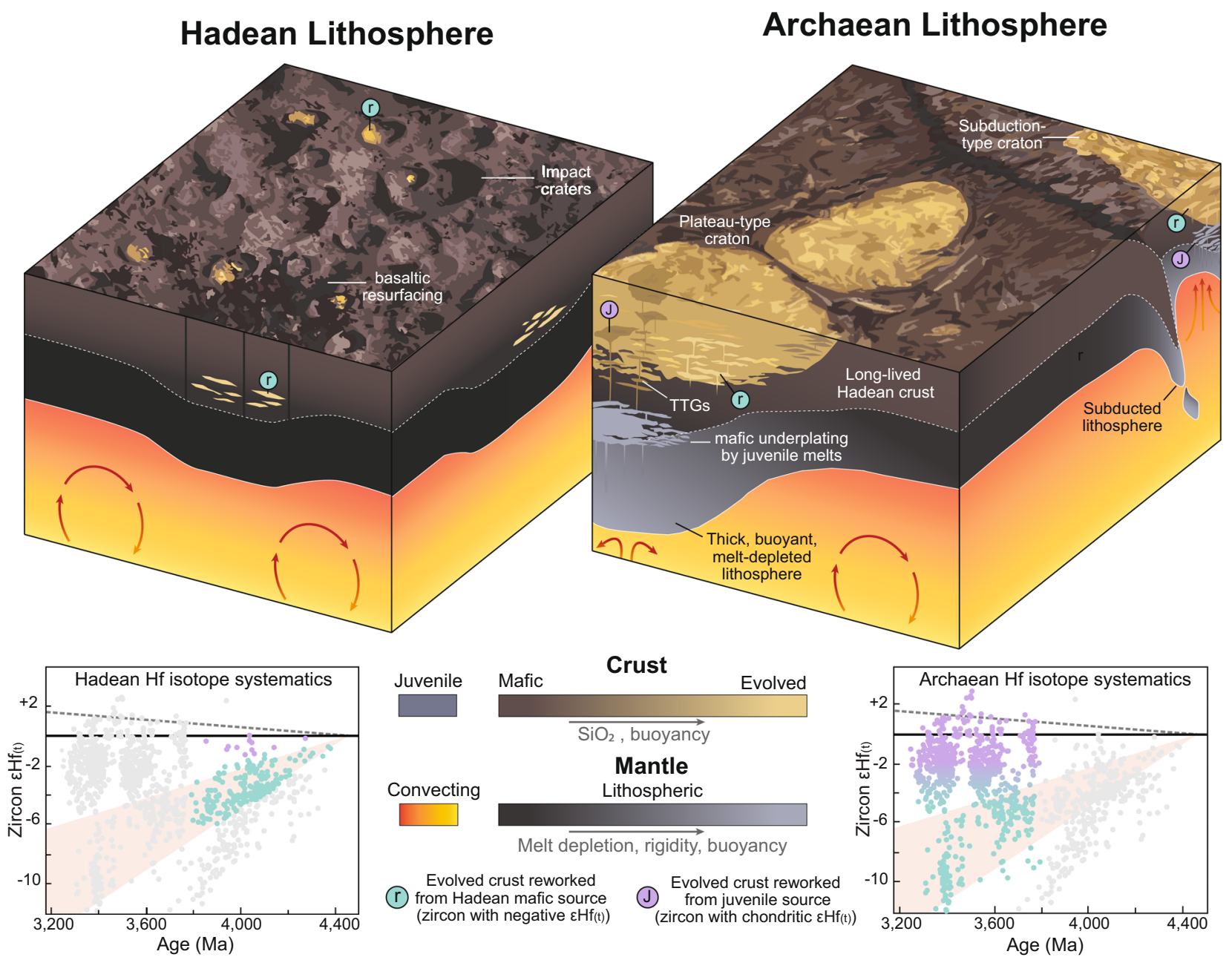

Evolved crust reworked

(C) from Hadean mafic source (zircon with negative $\varepsilon \mathrm{Hf}(\mathrm{t})$ )
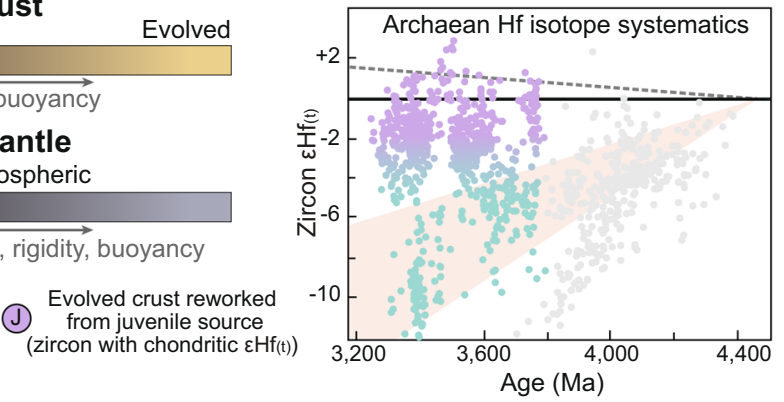

Fig. 4 Schematic diagrams illustrating changes in evolved crust-forming processes and lithospheric architecture between the Hadean and Archaean.

The Hadean crust is predominantly mafic-ultramafic with minor evolved melts formed by internal differentiation or impact melting. Hadean crust persists into the Archaean and is reworked in subduction zones or thick crustal plateaus above mantle upwellings to form evolved magmas that crystallise zircon with negative $\varepsilon \mathrm{Hf}_{(\mathrm{t})}$. These two tectonic settings also facilitate adiabatic or flux melting of convecting mantle to form juvenile mafic magmas, which are reworked to produce evolved magmas that crystallise zircon with approximately chondritic $\varepsilon \mathrm{Hf}_{(\mathrm{t})}$. Juvenile melt extraction produces a complementary meltdepleted, rigid, and buoyant lithospheric mantle, which stabilises the evolved crustal nuclei of Earth's first cratons. The zircon $\varepsilon \mathrm{Hf}_{(t)}$-time plots show the corresponding zircon-Hf isotope characteristics of evolved crust from the Yilgarn craton between the Hadean and Archaean eons.

contemporaneously with the appearance of the first stable, evolved crust in the Eoarchaean.

Although the development of stabilising depleted lithospheric mantle provides a plausible explanation for the increase in crustal preservation across the Hadean-Eoarchaean transition, the geodynamic trigger for this possible change in lithospheric architecture remains speculative. The scarcity of zircons with juvenile $\mathrm{Hf}$ isotopic signatures in the Yilgarn Craton prior to $\sim 3800 \mathrm{Ma}$ is compatible with stagnant-lid geodynamic models for the Hadean in which low-volume, evolved melts formed through remelting of mafic-ultramafic crust below overthickened volcanic centres ${ }^{10,14}$ or by meteorite impacts ${ }^{32}$ (Fig. 4). The switch to reworking of both Hadean and juvenile sources now recognised in the zircon $\mathrm{Hf}$ isotopic record of most early Archaean cratons between $~ 3850$ and $3600 \mathrm{Ma}$ (Fig. 3b, c) marks a fundamental and sustained change in the geodynamic setting of evolved crust production ${ }^{13}$. The observation that different cratons stabilised at different times over a period of at least $250 \mathrm{Ma}$ (Fig. 3c) suggests the change in global geodynamic regime was a transitional process ${ }^{13,33}$, rather than a response to a single cataclysmic event ${ }^{2}$. Previous studies have noted the similarity of these zircon-Hf isotope-time arrays to those produced in modern convergent margin systems $s^{34,35}$ and suggested that the global step-shifts in zircon-Hf isotope systematics (Fig. 3b) reflect the progressive onset of mobile-lid tectonics $3,13,22$. However, the extraction of isotopically juvenile precursors to zircon-bearing magmas is not unique to convergent margin settings. Early Archaean plateau-type terranes, such as the archetypal East Pilbara Terrane ${ }^{12,36}$, are inferred to have formed in a poorly mobile lid setting above long-lived mantle upwellings ${ }^{37,38}$, which presents an equally viable geodynamic setting for the production of evolved magmas with juvenile zircon-Hf isotopic compositions ${ }^{17,39}$. Although zircon-Hf isotope data alone is not diagnostic of the specific geodynamic processes operating in early Archaean, the key advance made by this study is to highlight that the distinct change in the geodynamic setting of crust formation across Hadean-Archaean transition was coincident with the stabilisation of the first cratons.

A link between craton stabilisation and a change in global geodynamics is supported by recent numerical models describing the thermochemical differentiation of the lithosphere across the Hadean-Archaean transition ${ }^{40}$. This modelling predicts that following long-term ( $500 \mathrm{Ma})$ stretching, a lithospheric lid will begin to thin and segment, resulting in large-scale decompression melting of the underlying convecting mantle. Due to the negative 
feedback between strain migration and lithospheric stiffening that accompanies melt-extraction, rift migration incorporates large volumes of rigid, melt-depleted mantle into the lithosphere, triggering the stabilisation of cratons. This process develops distinct geodynamic settings for crust formation depending on the strength of the modelled lithosphere. For a high strength lithosphere, new crust is produced over broad mantle upwellings below thinned regions of a poorly mobile lid, in a setting analogous to early Archaean plateau-type terranes. In contrast, mobile-lid behaviour can develop under lower lithospheric strengths as rifting of the lid into discrete tectonic plates is compensated by the development of subduction-like lithospheric downwellings ${ }^{30,40}$. In the context of this modelling, our new findings provide important geochemical and geological evidence for a fundamental change in the geodynamic setting of crust formation during the Hadean-Archaean transition, which facilitated the extraction of juvenile melts, crustal reworking, evolved magmatism, and the production of stabilising melt-depleted lithospheric mantle, which were critical to forming Earth's first cratons.

\section{Methods}

$\mathbf{U}-\mathbf{P b}-\mathbf{H f}$ isotopic analysis of zircon. Zircons were isolated from approximately 5 $\mathrm{kg}$ samples using standard magnetic and heavy liquid separation techniques. Zircons were cast into $25 \mathrm{~mm}$ round epoxy mounts, polished, and imaged using a Gatan PanaCL panchromatic CL detector housed at the University of Melbourne, Australia to characterise internal textures and aid in analytical spot placement.

$\mathrm{U}-\mathrm{Pb}$ and $\mathrm{Hf}$ isotopic data were collected via laser ablation split-stream inductively coupled plasma mass spectrometry at Monash University, Australia. The analytical set-up includes an ASI RESOLution $193 \mathrm{~nm}$ laser ablation system coupled to a Thermo Fisher iCAP TQ Triple Quadrupole inductively coupled plasma mass spectrometer for measurement of $\mathrm{U}$ and $\mathrm{Pb}$ isotopes and a Thermo Scientific Neptune Plus multicollector inductively coupled plasma mass spectrometer for measurement of $\mathrm{Lu}, \mathrm{Yb}$, and $\mathrm{Hf}$ isotopes. The ablated sample aerosol was split evenly using a Y-connector and transported to the mass spectrometers using polyurethane tubing with $\mathrm{N}_{2}$ gas added to the aerosol stream prior to arriving at the torch to enhance sensitivity. Laser ablation was preformed using a $35 \mu \mathrm{m}$ spot, a frequency of $8 \mathrm{~Hz}$, and a fluence of approximately $4.5 \mathrm{~J} / \mathrm{cm}^{2}$ (measured with an external fluence meter). Hafnium isotopes were collected following the method outlined in ref. ${ }^{41}$, which involved $30 \mathrm{~s}$ of background measurement and $60 \mathrm{~s}$ of ablation with a $1 \mathrm{~s}$ on-peak integration time. Dwell times for $\mathrm{U}, \mathrm{Th}$, and $\mathrm{Pb}$ isotopes on the iCAP TQ were $10 \mathrm{~ms}$ for ${ }^{238} \mathrm{U}$ and ${ }^{232} \mathrm{Th}, 20 \mathrm{~ms}$ for ${ }^{208} \mathrm{~Pb}, 70 \mathrm{~ms}$ for ${ }^{207} \mathrm{~Pb}, 40 \mathrm{~ms}$ for ${ }^{206} \mathrm{~Pb}$ and $30 \mathrm{~ms}$ for ${ }^{204} \mathrm{~Pb}$ and ${ }^{202} \mathrm{Hg}$. Isotopic data were reduced with the Iolite 3 software package ${ }^{42}$. The $\mathrm{U}-\mathrm{Pb}$ data was reduced with the U_Pb_Geochron4 data reduction scheme of Iolite with a smooth cubic spline used to model down-hole fractionation. The Hf isotopes were reduced using the Hf_isotopes data reduction scheme of Iolite with $\mathrm{Yb}$ mass bias corrected assuming ${ }^{173} \mathrm{Yb} /{ }^{171} \mathrm{Yb}=1.132685$ (ref. ${ }^{43}$ ) and Hf mass bias corrected assuming ${ }^{179} \mathrm{Hf} /{ }^{177} \mathrm{Hf}=0.7325$ (ref. ${ }^{44}$ ).

Natural zircon reference materials were measured every 15 unknowns during each analytical run and the drift between reference material brackets was corrected using a spline function. OG1 zircon ${ }^{45}$ was used to calibrate the $\mathrm{U}-\mathrm{Pb}$ data and the Mud Tank zircon ${ }^{46}$ was used to calibrate the Hf isotope data. Secondary standards were used to validate $\mathrm{U}-\mathrm{Pb}$ and $\mathrm{Hf}$ results and included the reference zircons $91500^{47}, \mathrm{GJ}^{48}$, Plešovice ${ }^{49}$, and QGNG ${ }^{50}$. The differences in the down-hole U-Pb fractionation behaviour of reference zircons with significantly different ages was accounted for by calibrating the U-Pb data for QGNG (1851 Ma) against OG1 $(3465 \mathrm{Ma}$ ) and calibrating the $\mathrm{U}-\mathrm{Pb}$ data for the younger reference zircons Plesovice (337 Ma), GJ1 (600 Ma), and Mud Tank (732 Ma) against 91500 (1063 $\mathrm{Ma}$ ). The weighted mean $\mathrm{U}-\mathrm{Pb}$ ages and ${ }^{176} \mathrm{Hf} /{ }^{177} \mathrm{Hf}$ values measured for the reference zircons agree with the published recommended values ${ }^{45-54}$, as do the stable $\mathrm{Hf}$ isotope ratios measured over all analytical runs ${ }^{55,56}$ (Supplementary Figs. 3 and 4). The ages reported for unknowns are ${ }^{207} \mathrm{~Pb} / 206 \mathrm{~Pb}$ ages with $2 \mathrm{SE}$ propagated uncertainties calculated by iolite and are uncorrected for common $\mathrm{Pb}$. Only analyses with $< \pm 10 \%$ discordance between their ${ }^{206} \mathrm{~Pb} /{ }^{238} \mathrm{U}$ and ${ }^{207} \mathrm{~Pb} /{ }^{206} \mathrm{~Pb}$ ages are considered in our interpretations. The ${ }^{176} \mathrm{Hf} /{ }^{177} \mathrm{Hf}$ and epsilon Hf values $\left(\varepsilon \mathrm{Hf}_{(\mathrm{t})}\right)$ at the time of crystallisation of the unknown zircons are calculated using their ${ }^{207} \mathrm{~Pb} /{ }^{206} \mathrm{~Pb}$ ages, the ${ }^{176} \mathrm{Lu}$ decay constant of ref. ${ }^{57}$, and the CHUR parameters of ref. ${ }^{58}$. The kernel density estimation and histogram of zircon $\mathrm{U}-\mathrm{Pb}$ ages and all weighted mean calculations were made using isoplot $\mathrm{R}^{59}$.

\section{Data availability}

All data used in this manuscript are included in the Supplementary Information File and Supplementary Data File 1.

\section{Code availability}

The Iolite code used for $\mathrm{U}-\mathrm{Pb}$ and $\mathrm{Hf}$ isotope data reduction is available at https://iolite. xyz/.

Received: 15 February 2021; Accepted: 12 May 2021; Published online: 10 June 2021

\section{References}

1. Marchi, S. et al. Widespread mixing and burial of Earth's Hadean crust by asteroid impacts. Nature 511, 578-582 (2014).

2. Griffin, W. L. et al. The world turns over: Hadean-Archean crust-mantle evolution. Lithos 189, 2-15 (2014)

3. Bell, E. A., Harrison, T. M., Kohl, I. E. \& Young, E. D. Eoarchean crustal evolution of the Jack Hills zircon source and loss of Hadean crust. Geochim. Cosmochim. Acta 146, 27-42 (2014)

4. Reimink, J. R. et al. No evidence for Hadean continental crust within Earth's oldest evolved rock unit. Nat. Geosci. 9, 777-780 (2016).

5. O’Neil, J., Carlson, R. W., Francis, D. \& Stevenson, R. K. Neodymium-142 evidence for Hadean mafic crust. Science 32, 1828-1831 (2008).

6. Harrison, T. M. Bell, E. A. \& Boehnke, P. Petrochronology: Methods and Applications. In Reviews in Mineralogy and Geochemistry. (eds Kohn, M. J., Engi, M. \& Lanari, P.) Vol 83 (The Mineralogical Society of America, Chantilly, Virginia, USA, 2017).

7. Nebel, O., Rapp, R. P. \& Yaxley, G. M. The role of detrital zircons in Hadean crustal research. Lithos 190, 313-327 (2014).

8. Froude, D. O. et al. Ion microprobe identification of 4100-4200 Myr-old terrestrial zircons. Nature 304, 616-618 (1983).

9. Schneider, K. P., Hoffmann, J. E., Boyet, M., Munker, C. \& Kroner, A. Coexistence of enriched and modern-like ${ }^{142} \mathrm{Nd}$ signatures in Archean igneous rocks of the eastern Kaapvaal Craton, southern Africa. Earth Planet. Sci. Lett. 487, 54-66 (2018).

10. Kamber, B. S. The evolving nature of terrestrial crust from the Hadean, through the Archaean, into the Proterozoic. Precambr. Res. 258, 48-82 (2015)

11. O’Neil, J. \& Carlson, R. W. Building Archean cratons from Hadean mafic crust. Science 355, 1199-1202 (2017).

12. Johnson, T. E., Brown, M., Gardiner, N. J., Kirkland, C. L. \& Smithies, R. H. Earth's first stable continents did not form by subduction. Nature 543, 239-242 (2017).

13. Bauer, A. M. et al. Hafnium isotopes in zircons document the gradual onset of mobile-lid tectonics. Geochem. Persp. Lett. 14, 1-6 (2020).

14. Kemp, A. I. S. et al. Hadean crustal evolution revisited: new constraints from $\mathrm{Pb}-\mathrm{Hf}$ isotope systematics of the Jack Hills zircons. Earth Planet. Sci. Lett. 296, 45-56 (2010)

15. Rapp, R. P. \& Watson, B. E. Dehydration melting of Metabasalt at $8-32$ kbar: implications for continental growth and crust-mantle recycling. J. Petrol. 36, 891-931 (1995).

16. Fisher, C. M. \& Vervoort, J. D. Using the magmatic record to constrain the growth of continental crust-the Eoarchean zircon Hf record of Greenland. Earth Planet. Sci. Lett. 488, 79-91 (2018).

17. Petersson, A., Kemp, A. I. S., Gray, C. M. \& Whitehouse, M. J. Formation of early Archean Granite-Greenstone Terranes from a globalyl chondritic mantle: Insights from igneous rocks of the Pilbara Craton, Western Australia. Chem. Geol. 551, 119757 (2020).

18. Kemp, A. I. S., Wilde, S. A. \& Spaggiari, C. Earth's oldest rocks 2nd edn (eds Van Kranendonk, M. J., Bennett, V. C. \& Hoffmann, J. E.) (Elsevier, 2019).

19. Amelin, Y., Lee, D.-C., Halliday, A. N. \& Pidgeon, R. T. Nature of the Earth's earliest crust from hafnium isotopes in single detrital zircons. Nature 399, 252-255 (1999).

20. Thern, E. R. \& Nelson, D. R. Detrital zircon age structure within ca. $3 \mathrm{Ga}$ metasedimentary rocks, Yilgarn Craton: elucidation of Hadean source terranes by principal component analysis. Precambr. Res. 214, 28-43 (2012).

21. Wyche, S., Lu, Y. \& Wingate, M. T. D. Earth's oldest rocks 2nd edn (eds Van Kranendonk, M. J., Bennett, V. C. \& Hoffmann, J. E.) (Elsevier, 2019).

22. Reimink, J. R., Pearson, D. G., Shirey, S. B., Carlson, R. W. \& Ketchum, J. W. F. Onset of new, progressive crustal growth in the central Slave craton at 3.55 Ga. Geochem. Persp. Lett. 10, 8-13 (2019).

23. Condie, K. C. Earth's oldest rocks 2nd edn (eds Van Kranendonk, M. J., Bennett, V. C. \& Hoffmann, J. E.) (Elsevier, 2019).

24. Guitreau, M., et al. Hadean Protocrust reworking at the origin of the Archean Napier Complex (Antarctica). Geochem. Persp. Lett. 12, 7-11 (2019).

25. Jordan, T. H. Composition and development of the continental tectosphere. Nature 274, 544-548 (1978)

26. Lee, C.-T., Yin, Q., Rudnick, R. L. \& Jacobsen, S. B. Preservation of ancient and fertile lithospheric mantle beneath the southwestern United States. Nature 411, 69-73 (2001). 
27. Carlson, R. W., Pearson, D. G. \& James, D. E. Physical, chemical and chronological characteristics of continental mantle. Rev. Geophys. 43, RG1001 (2005).

28. Griffin, W. L., \& O’Reilly, S. Y. Earth's oldest rocks 2nd edn (eds Van Kranendonk, M. J., Bennett, V. C., \& Hoffmann, J. E.) (Elsevier, 2019).

29. O'Neill, C., Debaille, V. \& Griffin, W. L. Deep earth recycling in the Hadean and constraints on surface tectonics. Am. J. Sci. 313, 912-932 (2013).

30. Capitanio, F. A., Nebel, O., Cawood, P. A., Weinberg, R. F. \& Clos, F. Lithosphere differentiation in the early Earth controls Archean tectonics. Earth Planet. Sci. Lett. 525, 115755 (2019).

31. van de Löcht, J. et al. Earth's oldest mantle peridotites show entire record of late accretion. Geology 46, 199-202 (2018).

32. Johnson, T. E. et al. An impact melt origin for Earth's oldest known evolved rocks. Nat. Geosci. 11, 795-799 (2018).

33. Cawood, P. A. et al. Geological archive of the onset of plate tectonics. Philos. Trans. R. Soc. A 376, 20170405 (2018).

34. Kemp, A. I. S. et al. Hf and O isotope evidence for rapid continental growth during accretionary orogenesis in the Tasmanides, eastern Australia. Earth Planet. Sci. Lett. 284, 455-466 (2009).

35. Næraa, T. et al. Hafnium isotope evidence for a transition in the dynamics of continental growth 3.2 Gyr ago. Nature 485, 627-630 (2012).

36. Van Kranendonk, et al. Earth's Oldest Rocks (eds Van Kranendonk, M. J., Bennett, V. C. \& Hoffmann, J. E.) (Elsevier, 2019).

37. Bedard, J. H. A catalytic delamination-driven model for coupled genesis of Archaean crust and sub-continental lithospheric mantle. Geochim. Cosmochim. Acta 70, 1188-1214 (2006).

38. Johnson, T. E., Brown, M., Kaus, B. J. P. \& VanTongeren, J. A. Delamination and recycling of Archaean crust caused by gravitational instabilities. Nat. Geosci. 7, 47-52 (2014).

39. Gardiner, N. J. et al. Processes of crust formation in the early Earth imaged through Hf isotopes from the East Pilbara Terrane. Precambrian Res. 297, 56-76 (2017).

40. Capitanio, F. A., Nebel, O. \& Cawood, P. A. Thermochemical lithosphere differentiation and the origin of cratonic mantle. Nature 588, 89-94 (2020).

41. Fisher, C. M., Vervoort, J. D. \& DuFrane, S. A. Accurate Hf isotope determinations of complex zircons using the "laser ablation split stream" method. Geochem. Geophys. 15, 121-139 (2014).

42. Paton, C., Hellstrom, J., Paul, B., Woodhead, J. \& Hergt, J. Iolite: freeware for the visualisation and processing of mass spectrometric data. J. Anal. Spectrom. 26, 2508-2518 (2011).

43. Chu, N. et al. Hf isotope ratio analysis using multi-collector inductively coupled plasma mass spectrometry: an evaluation of isobaric interference corrections. J. Anal. Spectrom. 17, 1567-1574 (2002).

44. Patchett, P. J. \& Tatsumoto, M. Lu-Hf total-rock isochron for the eucrite meteorites. Nature 288, 571-574 (1980).

45. Stern, R. A., Bodorkos, S., Kamo, S. L., Hickman, A. H. \& Corfu, F. Measurement of SIMS instrumental mass fractionation of $\mathrm{Pb}$ isotopes during zircon dating. Geostand. Geoanal. Res. 33, 145-168 (2009). 2009.

46. Woodhead, J. D. \& Hergt, J. M. A preliminary appraisal of seven natural zircon reference materials for in situ Hf isotope determination. Geostand. Geoanal. Res. 29, 183-195 (2005).

47. Wiedenbeck, M. et al. Three natural Zircon standards for U-Th-Pb, Lu-Hf, trace element and Ree analyses. Geostand. Geoanal. Res. 19, 1-23 (1995).

48. Jackson, S. E., Pearson, N. J., Griffin, W. L. \& Belousova, E. A. The application of laser ablation-inductively coupled plasma-mass spectrometry to in situ U-Pb zircon geochronology. Chem. Geol. 211, 47-69 (2004).

49. Sláma, J. et al. Plešovice zircon-a new natural reference material for $\mathrm{U}-\mathrm{Pb}$ and Hf isotopic microanalysis. Chem. Geol. 249, 1-35 (2008).

50. Black, L. P. et al. The application of SHIRIMP to Phanerozoic geochronology; a critical appraisal of four zircon standards. Chem. Geol. 200, 171-188 (2003).

51. Kemp, A. I. S., Vervoort, J. D., Bjorkman, K. E. \& Iaccheri, L. M. Hafnium isotope characteristics of Palaeoarchaean Zircon OG1/OGC from the Owens Gully Diorite, Pilbara Craton, Western Australia. Geostand. Geoanal. Res. 41, 659-673 (2017).

52. Woodhead, J., Hergt, J., Shelly, M., Eggins, S. \& Kemp, R. Zircon Hf-isotope analysis with an excimer laser, depth profiling, ablation of complex geometries, and concomitant age estimation. Chem. Geol. 209, 121-135 (2004).
53. Blichert-Toft, J. The Hf isotopic composition of zircon reference material 91500. Chem. Geol. 253, 252-257 (2008).

54. Morel, M. L. A. et al. Hafnium isotope characterization of the GJ-1 zircon reference material by solution and laser-ablation MC-ICPMS. Chem. Geol. 255, 231-235 (2008).

55. Blichert-Toft, K. \& Albarede, F. The Lu-Hf isotope geochemistry of chondrites and the evolution of the mantle-crust system. Earth Planet. Sci. Lett. 148, 243-258 (1997).

56. Spencer, C. J., Kirkland, C. L., Roberts, N. M. W., Evans, N. J. \& Liebmann, J. Strategies towards robust interpretations of in situ zircon Lu-Hf isotope analyses. Geosci. Front. 11, 843-853 (2020).

57. Söderlund, U., Patchett, P. J., Vervoort, J. D. \& Isachsen, C. E. The ${ }^{176} \mathrm{Lu}$ decay constant determined by Lu-Hf and U-Pb isotope systematics of Precambrian mafic intrusions. Earth Planet. Sci. Lett. 219, 311-324 (2004).

58. Bouvier, A., Vervoort, J. D. \& Patchett, P. J. The Lu-Hf and Sm-Nd isotopic composition of CHUR: constraints from unequilibrated chondrites and implications for the bulk composition of terrestrial planets. Earth Planet. Sci. Lett. 273, 48-57 (2008).

59. Vermeesch, P. IsoplotR: a free and open toolbox for geochronology. Geosci. Front. 9, 1479-1493 (2018)

\section{Acknowledgements}

This work was funded by Australian Research Council grant FL160100168 and Australian Research Council grant DP180100580. R. Pierson, M. Raveggi, and G. Hutchinson are thanked for technical assistance. T.J.I. publishes with permission from the Executive Director of the Geological Survey of Western Australia.

\section{Author contributions}

J.A.M and O.N conceived the project, conducted the field work, and collected the isotope data. P.A.C. and N.J.G assisted with geological interpretations and data compilation. A.N.W. assisted in collecting the isotope data. T.J.I. co-ordinated and assisted with the field work. All authors analysed the data and contributed to writing the paper.

\section{Competing interests}

The authors declare no competing interests.

\section{Additional information}

Supplementary information The online version contains supplementary material available at https://doi.org/10.1038/s41467-021-23805-6.

Correspondence and requests for materials should be addressed to J.A.M.

Peer review information Nature Communications thanks the anonymous reviewers for their contribution to the peer review of this work. Peer reviewer reports are available.

Reprints and permission information is available at http://www.nature.com/reprints

Publisher's note Springer Nature remains neutral with regard to jurisdictional claims in published maps and institutional affiliations.

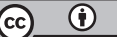

Open Access This article is licensed under a Creative Commons Attribution 4.0 International License, which permits use, sharing, adaptation, distribution and reproduction in any medium or format, as long as you give appropriate credit to the original author(s) and the source, provide a link to the Creative Commons license, and indicate if changes were made. The images or other third party material in this article are included in the article's Creative Commons license, unless indicated otherwise in a credit line to the material. If material is not included in the article's Creative Commons license and your intended use is not permitted by statutory regulation or exceeds the permitted use, you will need to obtain permission directly from the copyright holder. To view a copy of this license, visit http://creativecommons.org/ licenses/by/4.0/.

(C) The Author(s) 2021 